\title{
Structures and morphotectonic evolution of the frontal fold-thrust belt, Kameng river section, Arunachal Himalaya, India
}

\author{
T K Goswami ${ }^{1}$, D Bezbaruah ${ }^{1}$, Soumyajit Mukherjee ${ }^{2, *}$, \\ R K SARMAH ${ }^{1}$ and S JABEED ${ }^{1}$ \\ ${ }^{1}$ Department of Applied Geology, Dibrugarh University, Dibrugarh 786 004, India. \\ ${ }^{2}$ Department of Earth Sciences, Indian Institute of Technology-Bombay, Powai, Mumbai 400 076, India. \\ *Corresponding author.e-mail: soumyajitm@gmail.com
}

MS received 26 May 2017; revised 19 November 2017; accepted 21 December 2017; published online 2 August 2018

The Neogene-Quaternary Siwalik foreland fold and thrust belt is studied for better understanding of tectonics along the Kameng river section of Arunachal Pradesh, India. The Kimi, Dafla, Subansiri, and the Kimin Formation correspond to Lower, Middle and Upper Siwaliks, respectively. The lithology in the foreland basin is dominantly sandstones, siltstones, claystones, carbonaceous shales, and boulder beds in the upper part. The structural style of the sedimentary sequence from the Main Boundary Thrust southward shows first order ramp-flat geometry. The brittle shear transfers slip across glide horizons to shallower depth. Repeated splay generations from a major regional-scale floor transfers slip from one glide horizon to another that shortens and thickens the crust. In the micro-scale, the lithological response in the structural development is well documented as pressure solution seams and other diagenetic deformation signatures. The basement asperity plays a significant role as the moving thrust front produced a major lateral ramp. The differential movement of the mountain front on both sides of the ramp is decipherable. This is especially true at the western part of the SE flowing Kameng river. The tectonic evolution of the area initiated with slip along the MBT $\sim 11$ Ma ago along with the deposition of the Siwalik sediments. With southward propagation of the mountain front, the foreland basin shifted towards S, produced splay thrusts from the Himalayan Frontal Thrust-1 (HFT-1), which has been uplifting the Kimin and the older terraces.

Keywords. Sub-Himalaya; cross-section balancing; brittle fault.

\section{Introduction}

Himalayan tectonics and seismicity are of international attention (Khanal and Robinson 2013; Mandal et al. 2015, 2016; Khanal et al. 2015a, b). In the Siwalik fold and thrust belt along the Kameng river section, Arunachal Pradesh (India), different thrusts with deformation younging towards the foreland side display 'top-to-foreland/SSE' slip.
Towards the Brahmaputra alluvium, with a very shallow depth of the detachment, a thrust develops a break backward or piggy back sequence (as in figures 10 and 11 in Poblet and Lisle 2011). From MBT near the Pinjoli Nala up to the HFT-1 traced $\mathrm{S}$ of the locality Bhalukpong (figure 1), the following are noted. (i) Several thrusts placed the older sedimentary Dafla sequence over the Subansiri sequence. (ii) Thrusting brought the Subansiri 


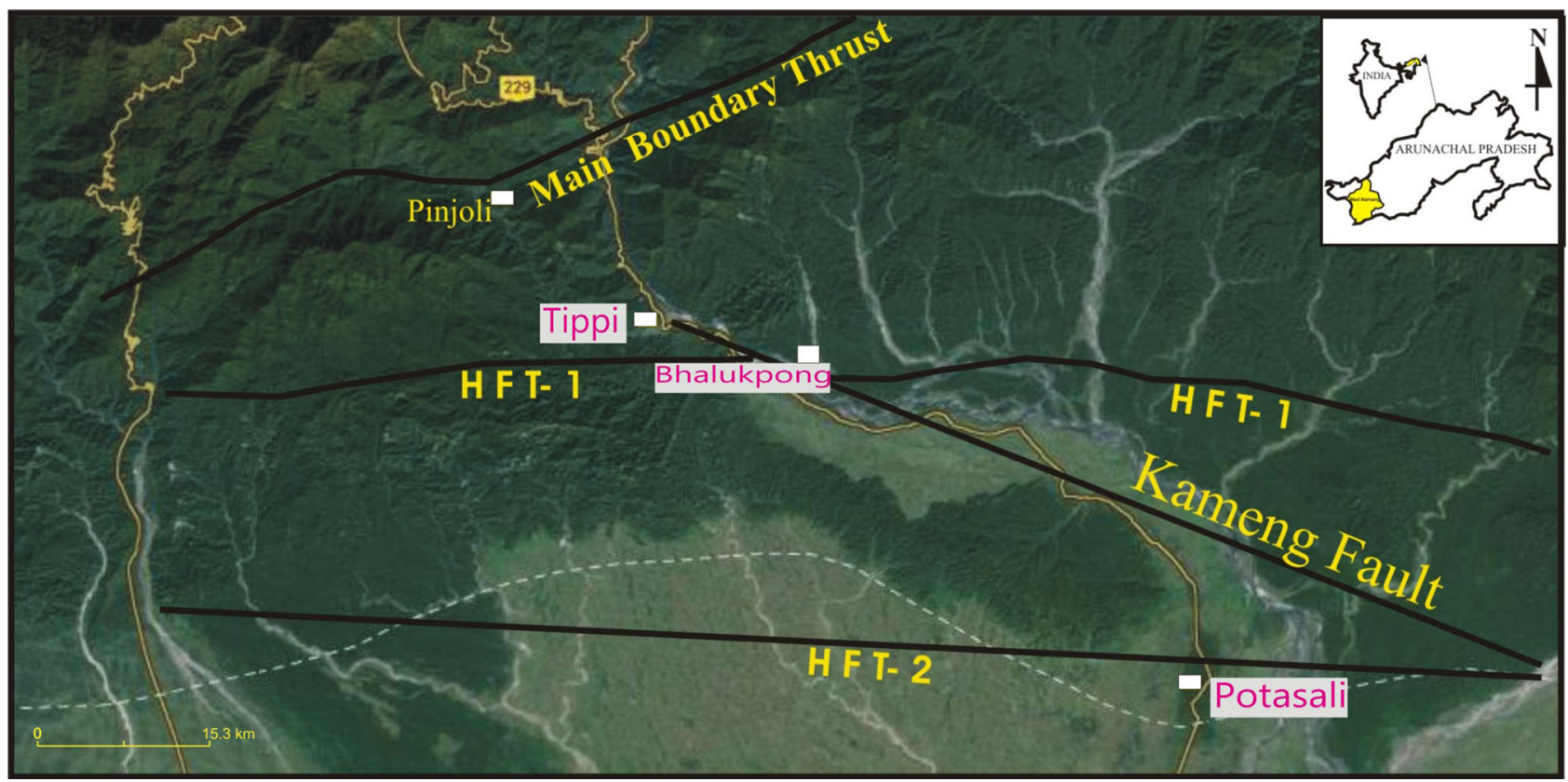

Figure 1. Google image of the area studied. Salient locations plotted. The MBT, HFT-1, HFT-2 and the Kameng Fault are shown with bold lines.

sequence over the Kimin sequence. (iii) Terraces were brought by thrusting above the Kimin unit. The rocks of the Kimin Formation and terraces are uplifted by the splay thrust from HFT-1.

We study in field deformation of the sedimentary sequence between MBT to the north and HFT-1 to the south. The final interpretation on the evolution of the structures is based on the construction of a cross-section, mapping of the terraces and interpreting the Neogene deformation style that can explain the active tectonics. Better understanding of tectonics is the aim of this work, which in long run, should assist in seismicity-related studies in this region.

\section{Himalayan geology}

\subsection{General information}

The Himalayan orogen is composed of four tectonostratigraphic zones. These are, from south to north (figure 1). (i) Sub-Himalaya: sedimentary marine, transitional marine to entirely nonmarine succession up to Mid Pleistocene age; (ii) Lesser Himalaya (LH): Proterozoic phyllites, slates, schists and gneisses; and (iii) Greater Himalayan Crystalline (GHC): Neoproterozoic schists and gneisses, Ordovician granitoids and $\sim$ Miocene leucogranites. The Sub-Himalaya is delimited by the Himalayan Frontal Thrust (HFT) at south and by the Main Boundary Thrust (MBT) at N. Main Central Thrust (MCT) is the contact between the $\mathrm{LH}$ and the GHC that is $\sim 1-10 \mathrm{~km}$ thick zone with the MCT-Lower $\left(\mathrm{MCT}_{\mathrm{L}}\right)$ at $\mathrm{S}$ and MCTUpper $\left(\mathrm{MCT}_{\mathrm{U}}\right)$ at north and contain a me'lange of $\mathrm{LH}$ and GHC rocks with several $\mathrm{P}-\mathrm{T}-\mathrm{t}$ conditions (review in Mukherjee 2015). The northern margin of the GHC is the South Tibetan Detachment System-Upper $\left(\operatorname{STDS}_{U}\right)$ that slipped first top-toSW and then top-to-NE (review in Yin 2006). A second extensional ductile shear zone STDSLower $\left(\mathrm{STDS}_{\mathrm{L}}\right)$ also occurs in GHC (Mukherjee and Koyi 2010). Deformation took place at the major fault planes at the following time ranges: $\mathrm{MCT}_{\mathrm{L}}:$ 15-0.7 Ma; $\mathrm{MCT}_{\mathrm{U}}:$ 25-14 Ma. Top-to-theNE shear in the $\operatorname{STDS}_{\mathrm{L}}$ : 24-12 Ma and that in STDS $_{\mathrm{U}}$ : 19-14 Ma (review in Godin et al. (2006)). MBT: 9-11 Ma; MFT: 2.5 Ma (Mukherjee 2013; Thakur et al. 2014). The MCT, MBT and MFT merge at depth into the Main Himalayan Thrust (MHT)/Main Detachment Thrust that is 'locked' at $\sim 15-20 \mathrm{~km}$ depth (Ader et al. 2012). The MHT is $\sim 6 \mathrm{~km}$ deep in Siwalik (Nepal: Schelling et al. 1991; Khanal et al. 2015a). Based on cross-section balancing, a minimum shortening rate of $8 \mathrm{~mm}$ $\mathrm{y}^{-1}$ is deduced from Siwalik range in Arunachal Pradesh (Kelty et al. 2004). Relevant review of tectonics of the Himalaya (or its specific issues) can be found in Thakur (1992, 2013), Mandal et al. (2015), Mukherjee et al. (2015), Martin (2017), etc. 


\subsection{Study area}

The Arunachal Himalaya (India) is located east of Bhutan (figure 1). Field-work and other geoscientific studies from this part of the Siwalik Himalaya (e.g., Verma and Tandon 1976; Valdiya 2003; Yin et al. 2006; Acharyya 2007; Srivastava and Mishra 2008) lacks detailed structural descriptions. The Indian lithospheric plate flexed and deformed presumably by in-sequence thrusting. Lithospheric flexure coupled with a thrust wedge developed of the foreland basin (Bhattacharya 2000; Yin 2006).

The lithology in the foreland basin dominantly composed of the sandstones-greywackes and lithic arenites, siltstones, claystones, carbonaceous shales, with boulder beds in the upper part.

Kelty et al. (2004) considered the following broad divisions of Siwalik in Arunachal Pradesh, regions bound between: (i) MFT and Tipi Thrust: N dipping monoclines, fault bent folds, and a series of anticlines and synclines (e.g., Papun syncline and Simna Parbat) in the Subansiri and Kimin Formation that are parts of hanging wall flat of the HFT, and (ii) MBT and Tipi Thrust: at least $6 \mathrm{~km}$ shortened $20-60^{\circ}$ dipping Dafla Formation (Kelty et al. 2004). Verma and Tandon (1976) deciphered from the structural analyses of the broad open folds and regional thrusts from Siwalik in Arunachal Himalaya. In the Kameng river section, the Siwalik Frontal Fold Belt expose from Pinjoli Nala in the W Kameng District up to Potasali in the Brahmaputra plain in Assam (figure 1). The structurally uppermost thrust in the MBT zone separates the Proterozoic rocks from the Permian rocks below. The north-dipping Permian strata below the Proterozoic Bomdila Group of rocks are inter-layered with phyllite, quartzite metavolcanics and carbonates (Yin et al. 2006). The Permian strata itself folded and faulted. The lowermost thrust of MBT places Permian rocks over the Tertiary Siwalik sequence (figure 2). In the Kameng section, $\sim \mathrm{N}$ dipping Tipi Thrust is in fact an intraformational thrust within Subansiri Formation. This is in contrast to the earlier report (Kelty et al. 2004) that the Tipi Thrust brought Lower Siwalik above the Upper Siwalik (Lang et al. 2016). The thrust merges with a decollement at depth (Kelty et al. 2004). Yin et al. (2006) referred that (i) the Tipi Thrust seems to be presently inactive; (ii) two back-thrusts exist in the hanging wall block of this thrust. Yin et al. (2006) stated the attitude of the Tipi Thrust to be N45E strike, $55^{\circ}$ dip towards NW. Chirouze et al. (2013) dated activity of Tipi Thrust at $\sim 1$ Ma. Yin et al.'s (2006) figure 4(b) shows a cross-section where the Tipi Thrust is traced. However, no other detail about this thrust is presented. MBT and Tipi Thrust uplifted at least $6 \mathrm{~km}$ of crustal layer (Lang and Huntington 2014). Sediments deposited near the Tipi Thrust faulted block while deformation was going on (Lang and Huntington 2014). De Sarkar et al. (2014) reported out-of-sequence thrusting of $<1$ ka age between Bhalukpong and Tipi villages produced by both profound erosion as well as critical tape condition. A thrust system within a sedimentary basin will preferably be deformed following the critical taper theory. Based on luminescence ages, they deciphered a significantly high c. $12 \mathrm{~mm} \mathrm{y}^{-1}$ slip rate and a c. $7 \mathrm{~mm} \mathrm{y}^{-1}$ rate of shortening.

The Miocene Dafla Formation (oldest Siwalik Unit: Srinivasan 2003) is thrust over the Pliocene Subansiri Formation $\sim 1 \mathrm{~km} N$ to the Tipi Thrust (figure 2a and b). The HFT-1 placed the Subansiri Formation over the Pliestocene Kimin Formation south of Bhalukpong. The area between Potasali and Bhalukpong is mostly covered by river terrace deposits (figure 3). From Pinjoli to Bhalukpong, the Dafla and Subansiri sequences indicate the ramp and flat geometry. Foreland dipping forelimb and hinterland dipping back limbs of the ramp anticlines are documented in the outcrops (figure $4 \mathrm{a}-\mathrm{d}$ ). From Bhalukpong to Potasali, five different levels of terrace $\left(T_{0}, T_{1}, T_{2}, T_{3}\right.$, and $\mathrm{T}_{4}$ ) are documented. Out of them, only the sedimentary beds in $\mathrm{T}_{4}$ terrace are tilted (figure $5 \mathrm{a}$ ). This indicates that the $\mathrm{T}_{4}$ terrace is comparatively older than other terraces. The terrace deposits lie unconformably (figure 5b) above the Kimin Formation (Upper Siwalik). From Upper Bhalukpong to Pinjoli Nala, Subansiri- and Dafla formations are parts of the fold and thrust sequence. We present a brief description of these mesoscopic structures in the inner sedimentary domain consisting of Dafla and Subansiri sequences. Kameng river takes a S/SE course from Tipi displacing only the Subansiri sequences in the Upper Bhalukpong area. Gondwana sequences exposed at the Pinjoli Nala are highly crumpled and carbonaceous shale at the core of the large antiform become phyllitic with interlayered quartzites of sigmoid shape.

River terraces are formed due to uplift and erosion of flood plain of the river. Therefore, the four levels of different terraces found at different elevations in the area indicate different phases of 


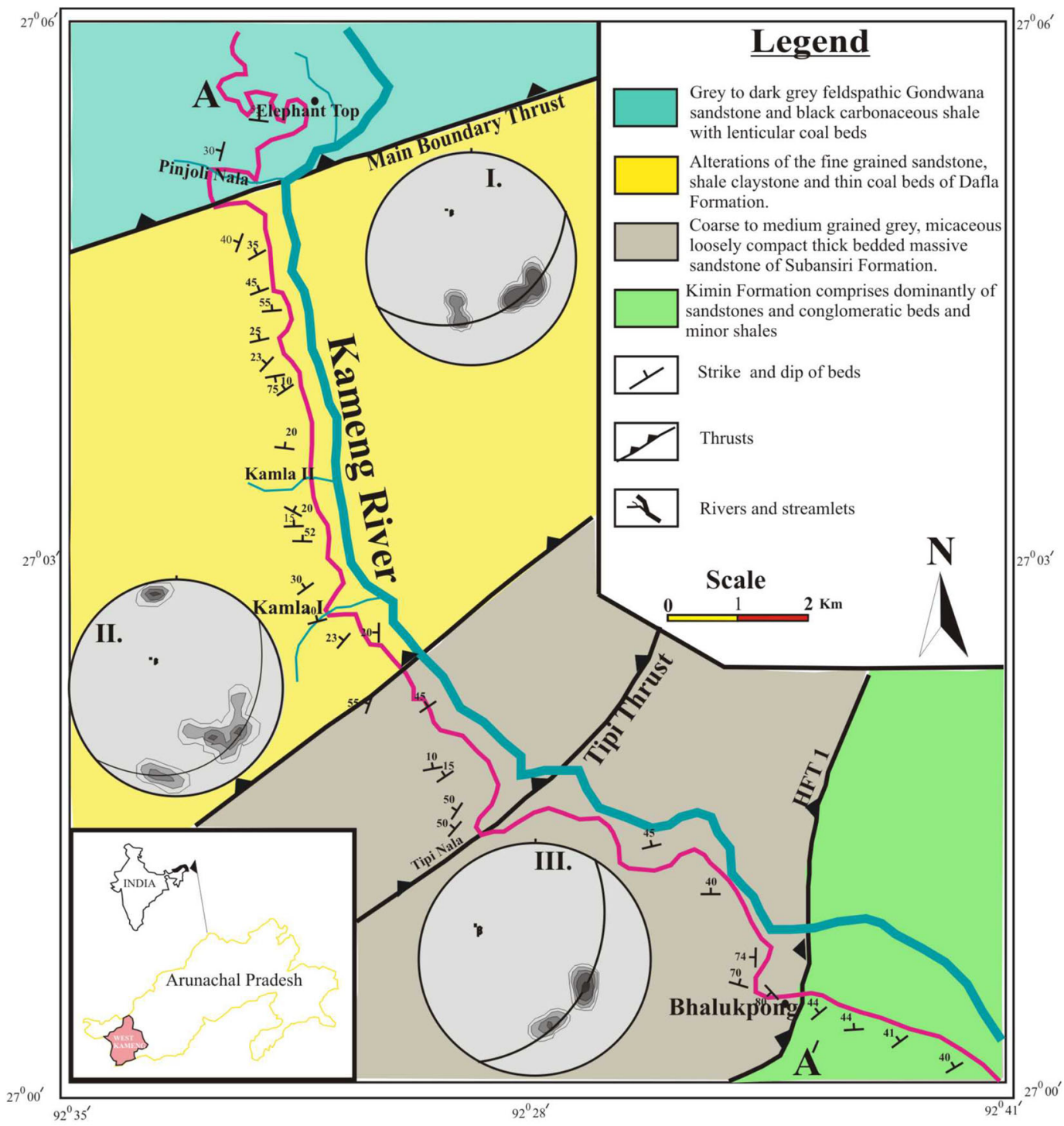

(a)

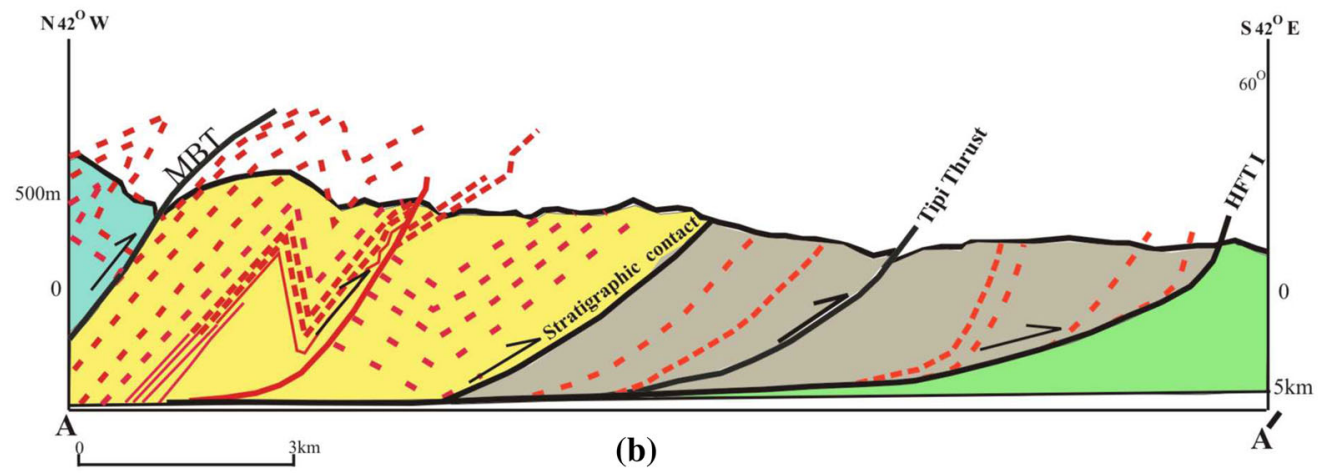

Figure 2. Geological map of the area between Bhalukpong and Pinjoli Nala. Three thrust slices are named as Pinjoli-Kamla, Kamla-Tippi and Tipi-Bhalukpong as can be shown in the cross section $\left(\mathrm{A}-\mathrm{A}^{\prime}\right)$ below the map. The attitudes of beds in three domains are shown with three lower hemisphere plots with number of plots respectively 55,60 and 45 and the contour intervals are $<3,6,9,12$ and $>15 \%$. 


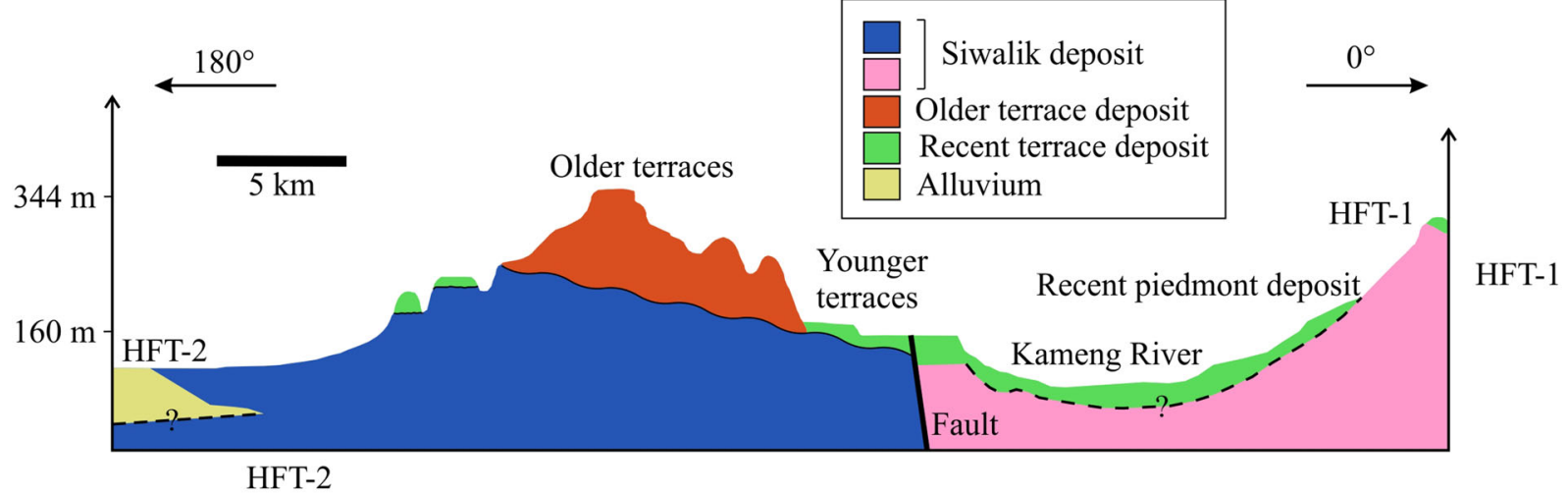

Figure 3. A cross-section in a region between Bhalukpong and Potasali.

uplift and erosion of older flood plain. These phases of uplift are not defined by coarsening or fining upward succession.

\section{Surface structural mapping and cross-section construction}

We mapped the area along the Kameng river from Pinjoli up to Potasali. Two cross-sections are constructed from Pinjoli to Potasali (figures 2 and 3 ). The Pinjoli-Bhalukpong profile utilizes the 'kink method' of drawing the cross-section based on limited attitude surface at the surface (Tearpock and Bische 2002). This method reconstructs folds with straight limbs and sharp hinges. This indicates that the back-limbs of thrust-related S/SW vergent fore-folds dip uniformly to NNW or NNE. The forelimbs dip steeply to SSW. If overturned, they dip NNE.

Structural geometry in the area can be divided into two domains:

- Domain A: the Dafla and Subansiri units, sandwiched between the MBT and the HFT-1, and

- Domain B: between HFT-1 and the Potasali: the Kimin unit expose and five terraces were mapped by us.

The outcrop-scale structures as studied from the Pinjoli Nala in the $\mathrm{N}$ up to Bhalukpong at $\mathrm{S}$ (Domain A). The scarp near Bhalukpong is the surface trace of the Bhalukpong Thrust (Yin et al. 2006). The Dafla and Subansiri units N of the Bhalukpong Thrust is folded controlled by ramps and flat geometry of the faults and duplexes.

An overall ramp and flat geometry and thrust sheets/slices is displayed S to MBT (figure 2). These are: (i) Pinjoli-Kamla slice: here the entire
Dafla sequence is asymmetric parallel folded (Class 1B) anticlinally and synclinally folded. The back limbs of the anticlines dip gently to NNE/NNW (figure $4 \mathrm{a}, \mathrm{b}$ ) and the forelimb dips to NNW and SSE. The folds are overturned at places: both the forelimb and the back limb dips towards NNW. However, beyond the Kamla river (Bridge-2), the forelimb dip does not increase. Brittle shear planes dip mostly towards the hinterland (figure 4c, d).

Kamla-Tipi slice: The forelimb displays numerous second-order folds and the anticlinal axis reorients possibly due to asperities in the thrust plane or changes in the orientation of the compression in the internal domain of the Dafla. The forelimb of a large ramp antiform dips steeply towards the foreland side (figure 4e).

We observe a thrust contact between the Dafla and the Subansiri unit at Tipi. The fault scarp containing shear senses are shown in figure 2 .

Tipi-Bhalukpong slice: The Tipi thrust strikes $\mathrm{N} 55^{\circ} \mathrm{E} / \mathrm{S} 66^{\circ} \mathrm{W}$ and dips $\sim 50^{\circ}$ towards $\mathrm{N} 24^{\circ} \mathrm{W}$ (figure 2). The steep scarp in the Upper Bhalukpong area connotes uplift of the Siwalik rocks and the older Terrace $\left(\mathrm{T}_{4}\right)$ in the Upper Bhalukpong area. This reverse fault is marked as HFT-1 (figure 2). The Subansiri sandstones dip at moderate angle towards NNW in the Upper Bhalukpong area (figure 4f). The Kimin Formation expose S to HFT-1.

As the thrust brings the Dafla Formation above the Subansiri Formation, the thrust might have developed after deposition of Subansiri Formation. Therefore, depth of the thrust is within the range of combined stratigraphic thickness $(\sim 8 \mathrm{~km}$, Kumar 1997) of Dafla and Subansiri formations.

Regarding figure 3, the cross section is drawn close to the mountain front where Kameng river 

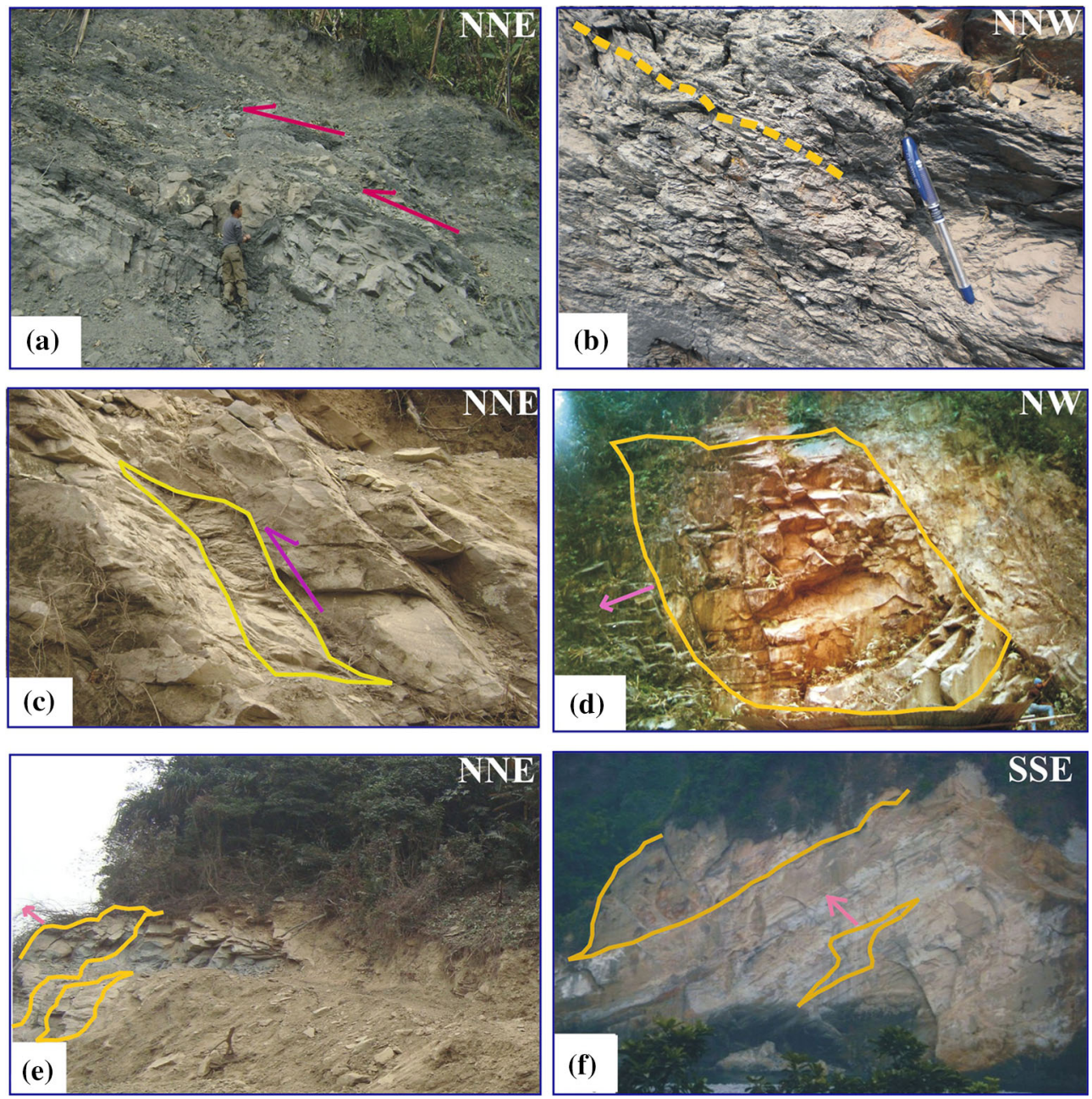

Figure 4. (a) Carbonaceous shale and sandstone sequence of the Bhareli Formation near Pinjoli Nala showing top-to-SSW shear sense. (b) The carbonaceous shale bed become phylitic near the axial plane of a large antiform. (c) Hinterland dipping duplex within the Dafla sandstone near Kamla Bridge 1. Top-to-SSW slip is noted. (d) Large hinterland dipping duplex in the Dafla sandstone near Kamla Bridge 2. The slip is top-to-SSE. (e) Antiformal stack and foreland dipping duplex in the Dafla sandstone at $2 \mathrm{~km}$ north of Tipi Nala. (f) Hinterland dipping ramp in the Subansiri sandstone near Bhalukpong.

comes out of the mountain. Further, the rocks of Kimin Formation are weak and friable, it is easily erodible. Therefore, in this location mountain front recede further north which results in low topography where HFT-2 is present.

\section{Neotectonics and evolution of the Siwalik foreland basin}

The Siwalik molasse deposited in the study area while the MBT acted as a basin margin fault (figure 6a). Subsequent compression produced imbricated thrust slices within the inner sedimentary sequences at the foreland basin margin (Lower Bhalukpong area). The piggy-back basin in the Lower Bhalukpong area formed when thrust-front propagated south forming piggy-back basin behind the thrust. The HFT slipped during Late Pleistocene when the foreland basin compressed intensely (Valdiya 1998). This compression probably produced tectonic inversion. This plausibly reactivated normal faults in the basement craton as thrust faults. Subsequently, the Siwalik rocks got involved in the Himalayan orogeny (figure $6 \mathrm{~b}$ ).

The HFT-1 uplifted the Siwalik and the older terrace $\left(\mathrm{T}_{4}\right)$ in the Upper Bhalukpong area. Further movement along the frontal fault deformed Siwalik sediments. Siwalik sediments along with Quaternary deposit were further thrust over the recent Brahmaputra alluvium. This episode activated another thrust fault that branch out from the HFT-1 and changed Kameng river course (figure 6c). 

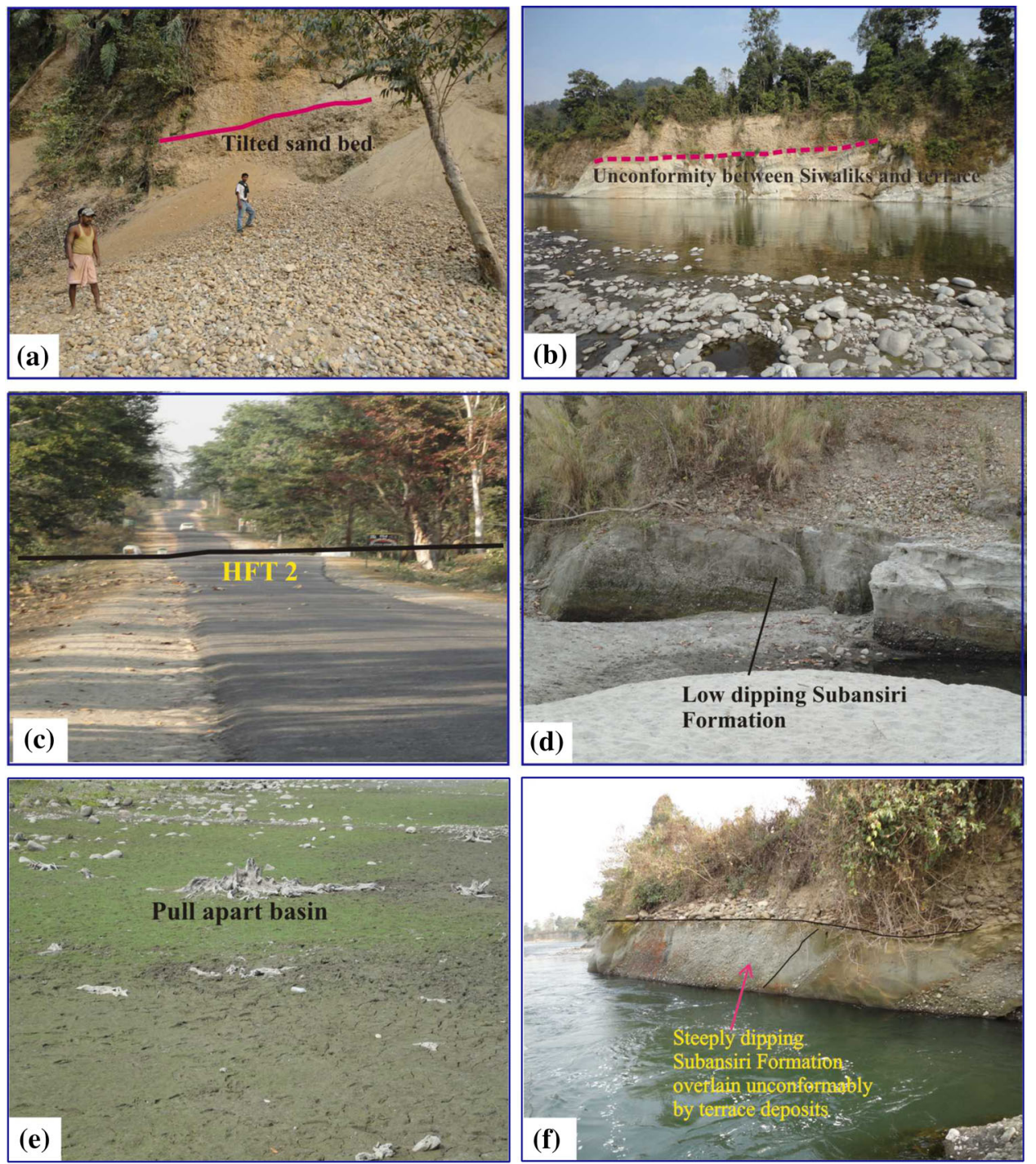

Figure 5. (a) Tilted strata in the $\mathrm{T}_{4}$ level terrace. (b) Terrace deposit lying unconformably above the Kimin sandstones near Lower Bhalukpong. (c) Sharp change in the topography indicates surface trace of the HFT-2. (d) Gently dipping Kimin sandstone in the flat part of the HFT-2. (e) Swampy area adjacent to the Kameng fault about 5 km SSE of Lower Bhalukpong. (f) Steeply dipping Kimin beds in the ramp of HFT-2 4 km south-southeast of Lower Bhalukpong.

The HFT-2 uplifted the older terrace deposit (older alluvial fan of Kameng river), which is the range bounding fault here. The part of the uplifted alluvial fan restrict the older course of the Kameng river and the channel diverted to the present course. Note in figure 1, the raised terraces are at the SW part, the Kameng fault trends NW, parallel to the Kameng river. The Kameng fault post-dated HFT-2 as indicated by the offset of the mountain front in the area. The rocks of the Kimin Formation is unconformably overlain by terrace deposit exposed in the river bank near the mountain front in the area. This indicates the presence of HFT-2 in the area.

The initial development of HFT was a phase when the first cycle of compression ended and no thrusts developed within HFT and MBT. However, renewed compression developed HFT-1 and HFT2 as splays, possibly in an out-of-sequence manner (Mukherjee 2015, review). Probably during Early Holocene, the HFT-2 (figure 5c) uplifted the older deposits that changed the course of Kameng river to $\mathrm{E}$ trend and formed the present day piggy-back basin. During this episode of uplift, the Terrace $\mathrm{T}_{4}$ elevated as the HFT-2 developed ramp and flat structures (figure $5 \mathrm{~d}, \mathrm{f}$ ). Tilted sedimentary bed in Terrace $\mathrm{T}_{4}$ specifically indicates this (figure $6 \mathrm{~d}$ ).

Further uplift of the HFT and back tilting during Holocene, which is indicated by uplifted older terrace deposits of the area, changed the river course. The next phase of tectonic adjustment is manifested by the advancement of the 

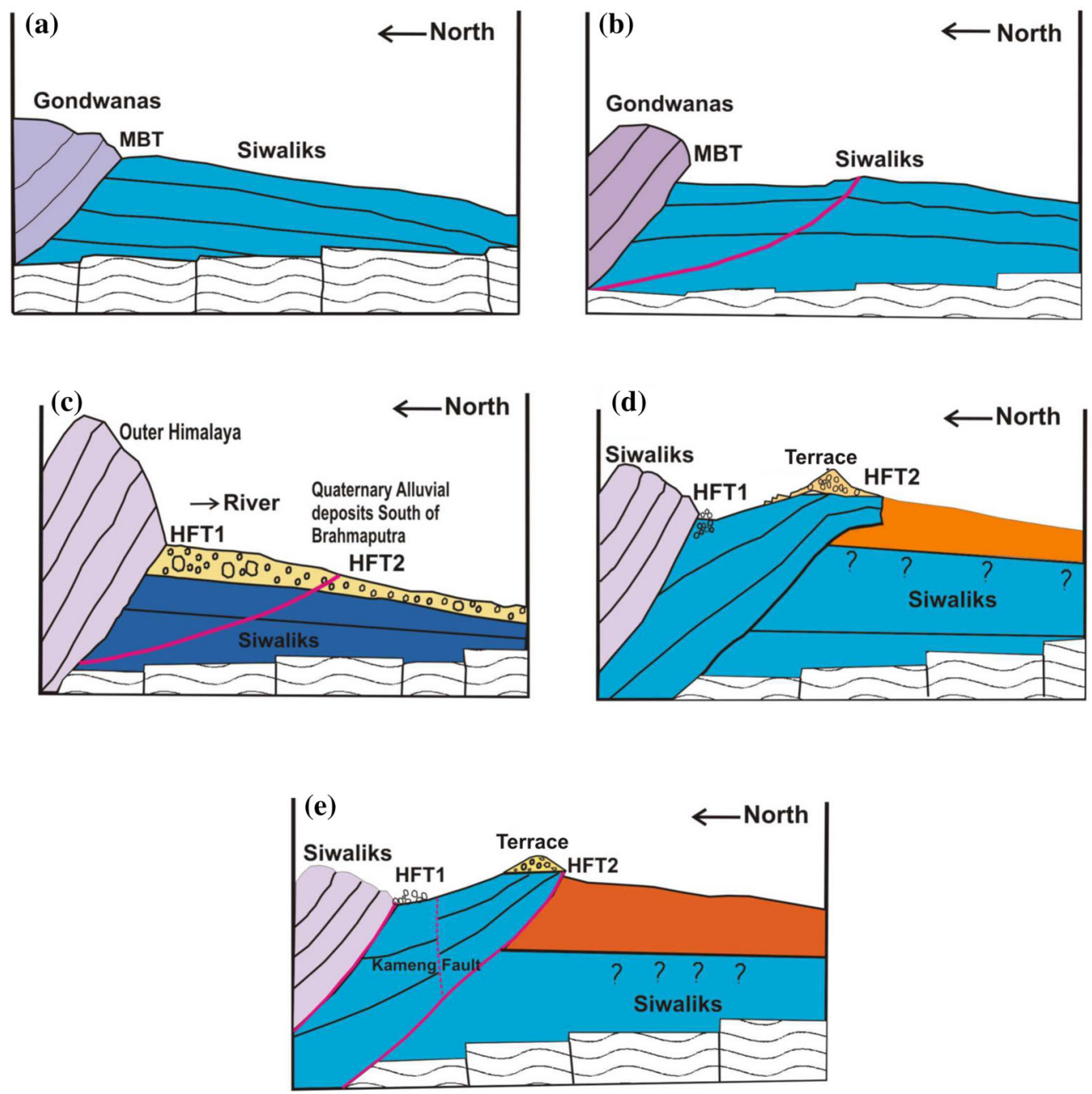

Figure 6. (a) The Siwalik molasses sediments were deposited in this foredeep basin where MBT acted as the basin margin fault. (b) Intense compressed foredeep basin resulted in the formation of a splay thrust which is known as HFT-1 inversion of a normal fault as the HFT-1 uplifted the Siwaliks and the older terrace $\mathrm{T}_{4}$ in the Upper Bhalukpong area. (c) Branching out of HFT-2 responsible for the change in the course of Kameng river. (d) $\mathrm{T}_{4}$ terrace got elevated when HFT-2 override the Brahmaputra alluvium. (e) Accommodation of the movement oblique to the HFT and formation of Kameng strike slip fault and formation of extensional basins.

mountain front towards south. Such an advance is accommodated by the strike slip fault, as the thrust slice on either side of the Kameng river experienced differential resistance to movement. Small pull apart basins are formed due to this strike slip. These basins adjacent to the strike slip faults are observed in the field in the form of marshy and swampy areas (figures 5e and 6e).

\section{Slip transfer in micro-scale}

Oriented samples, collected from Pinjoli Nala to Bhalukpong (figure 1), form Dafla and Subansiri sandstones across different subsidiary thrust contact show that slip transferred from one glide plane to another in NNW-SSE sections, as recorded under an optical microscope. Kinked micas observed in soft clays and shales of Dafla Formation indicate differential slip along the basal (001) cleavage (figure 7a). Some of the quartz grains are fractured (figure 7b) and even indicate duplex structures (figure 7c). Interestingly, Mukherjee (2012a, b) demonstrated such brittle deformation from micro-scales from other Himalayan shear zones. The metamorphic rock fragments mimic the sense of shear of the authigenic host biotite grains (figure 7d). Post-depositional compaction commonly produces grains in concavo-convex and sutured contacts. We negated such textures in tectonic interpretation.

\section{Discussions and conclusions}

Between MBT and HFT-1, imbricate faulted thrust slices of Dafla, Subansiri and Kimin sequences 


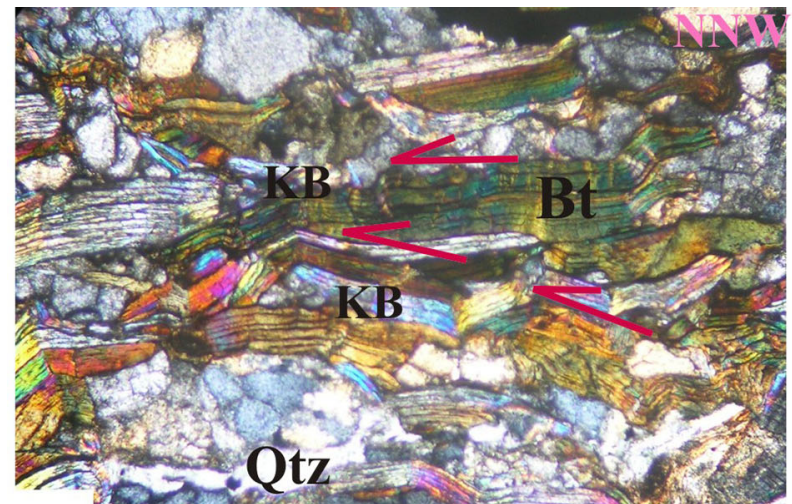

(a)
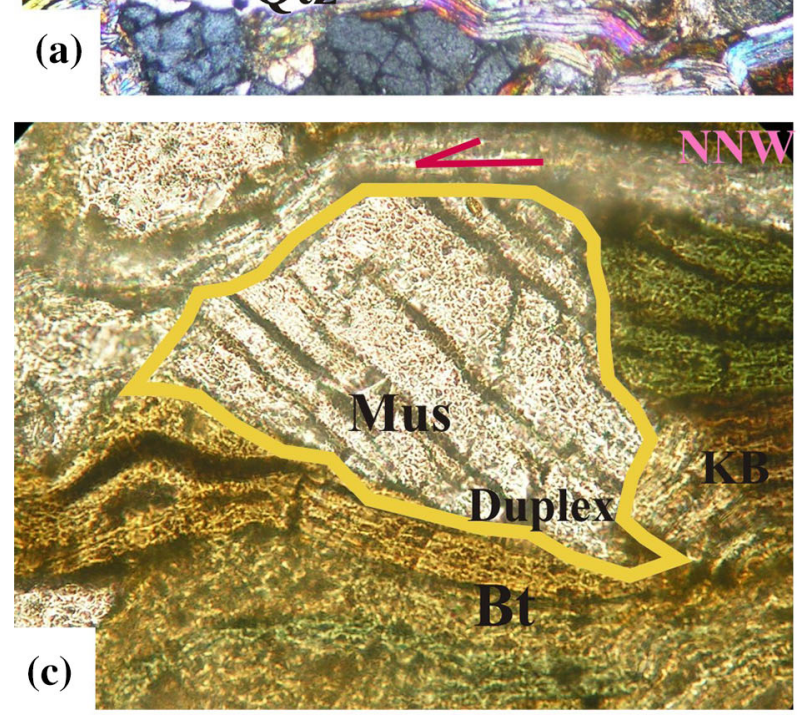
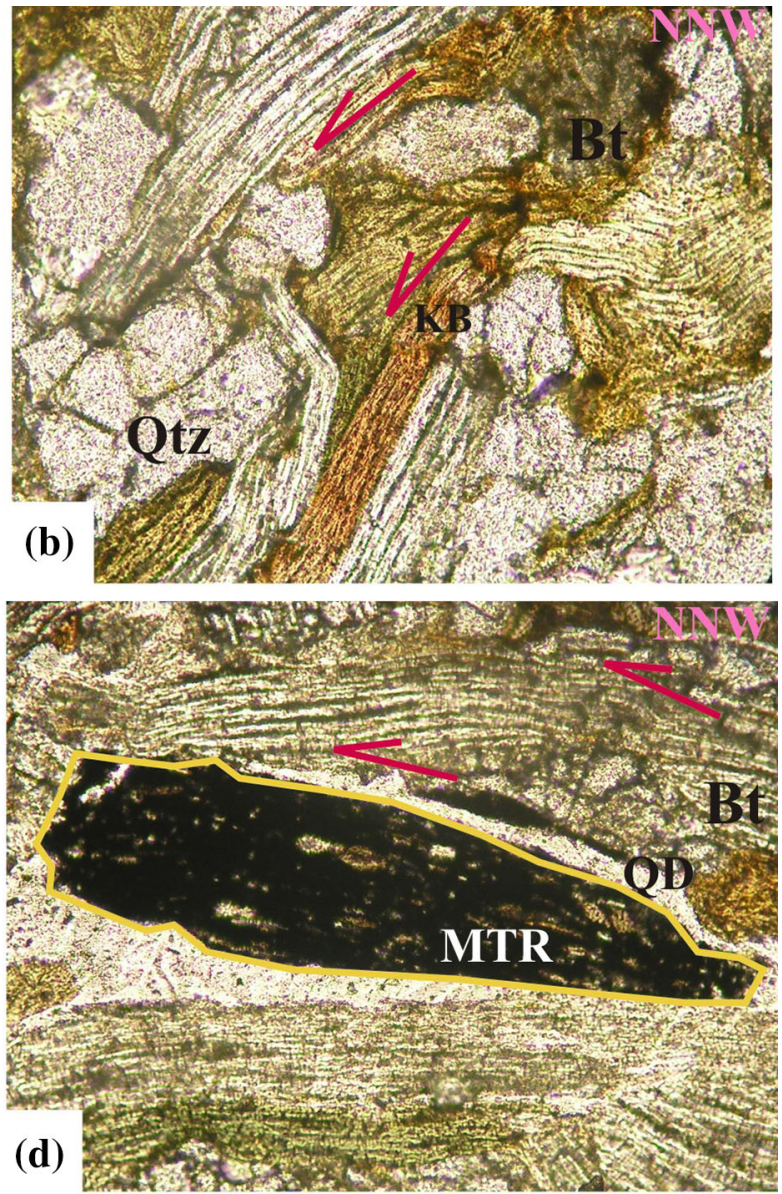

Figure 7. Microscopic kink bands especially in shale layers in the Dafla sequence indicate how the slip transfer process is pervasive up to the grain scale. (a and b) Kink band in biotite indicate differential movement of the basal (001) cleavage front; quartz grains brittle fractured; (c) muscovite fish showing top-to-SSE slip. Ductile deformed quartz indicates deformation at $\sim 650{ }^{\circ} \mathrm{C}$ (Passchir and Trouw 2005). This could be inferred as shear heat generated during imbrications and cataclasis in the Dafla sandstones. (d) The metamorphic rock fragments (mrf) mimic the sense of shear of the host authigenic biotite grains. kb: kink bands, bt: Biotite, mus: Muscovite qtz: quartz, qd: quartz dissolution.

along the Kameng section indicate structural geometry of the foreland verging fold and thrust sequence. The overall geometry is the ramps and flats. The rear of the ramp down-flexed and dip gently towards NNE/NNW. The frontal part dips steeply towards SSE/SSW and at places overturned toward NNE/NNW. From Pinjoli Nala to Tipi, both Dafla and Subansiri sequences are highly imbricated consisting of several zones of cataclasis. The Dafla-Subansiri contact is not present at Tipi. This contradicts the previous mention by Yin et al. (2006) that the contact is at Tipi. The stratigraphic contact between Dafla and Subansiri sequence is in fact north of Tipi and at higher structural level. Therefore, we interpret the Tipi Thrust to be an intra-formational thrust within the Subansiri sequence. The grain-scale deformation varies from quasi-plastic to brittle, some of which are syn-diagenetic (Goswami and Sarmah
2013; see Labaume 1987 for such cases from a different terrain).

The Kameng river is destabilized during Holocene due to tectonic adjustments of the frontal faults. This is also supported by phases of aggradations and incisions (Srivastava and Mishra 2008). The uplift of the older deposits changed river track towards east and concomitantly formed the piggy back basins. As the HFT-2 overrides the Brahmaputra alluvium along a ramp, the $\mathrm{T}_{4}$ terrace uplifted. The river course kept changing with the further uplift by HFT-2. In the next phase, with the continued movement of the Indian plate, the advancement of the mountain front could be accommodated by a strike slip fault oblique to the HFT. The strike slip fault created a few local extensional mini-basins as can be seen in the field in the form of marshy and swampy areas (north of Balipara). The development of piggy-back basins 
between HFT-1 and HFT-2 in the next phase indicates decrease in the deposition rate compared to the rate of thrusting, syn-orogenic deposits are deformed and local angular unconformities and erosional surface occur (Burbank and Verges 1994). Because of this, spreading and extension of the mountain front continued more towards south. Thus, the Kameng river changed its course and many unpaired terraces are left in its earlier path. Note the Kimin is overlain unconformably by terrace deposit in the area. The HFT uplifted both the deposit. Therefore, terrace deposit lie above the Kimin Formation.

The Kameng seismogenic fault was initially marked by Srivastava and Mishra (2008; their figure 1) to be $\sim \mathrm{N}$ trending for $\sim 10 \mathrm{~km}$ and passing close to Bhalukpong. However, we would change the trend of the Kameng Fault to be NW trending (figure 1) in a more regional-scale. We retain this fault passing close to Bhalukpong, as done earlier by Srivastava and Mishra (2008). This fault is a strike-slip one and might develop by differential block movement along the Himalayan front. Therefore, this fault must have continued up to the mountain front. But maps of the earlier workers show abrupt termination of this fault against the foot of $\mathrm{T}_{4}$ Terrace. So the location and extent of the marked fault in the present study is more justified.

\section{Acknowledgements}

TKG, DB, RKS and SJ thank the previous Head of the Department for support. They are grateful to the University Grants Commission (UGC) for providing Special Assistance Program to the Department, which partly supported the fieldwork. TKG thanks additionally to the UGC for providing financial support: grant number: F.N. 411025/2012 (SR), 2012. SM acknowledges IIT Bombay's CPDA grant. A research sabbatical assigned by IIT Bombay to SM for the year 2017 helped to finish this manuscript. Thanks to the anonymous reviewer for the positive comments in great detail, and Prof. Saibal Gupta for handling this article.

\section{References}

Acharyya S K 2007 Evolution of the Himalayan Paleogene foreland basin, influence of its litho-packet on the formation of thrust-related domes and windows in the Eastern Himalayas - A review; J. Asian Earth Sci. 31 1-17.
Ader T and Avouac J-P et al. 2012 Convergence rate across the Nepal Himalaya and interseismic coupling on the Main Himalayan Thrust: Implications for seismic hazard; $J$. Geophys. Res. Solid Earth 117 B04403.

Bhattacharya A R 2000 Deformational regimes across the Kumaun Himalaya: A study in strain patterns; Gond. Res. Memoir 6 81-90.

Burbank W D and Verges J 1994 Reconstruction of topography and related depositional systems during active thrusting; J. Geophys. Res. 3 1-25.

Chirouze F, Huyghe P, van der Beek P, Chauvel C, Chakraborty T, Dupont-Nivet G and Bernet M 2013 Tectonics, exhumation, and drainage evolution of the eastern Himalaya since 13 Ma from detrital geochemistry and thermochronology, Kameng River Section, Arunachal Pradesh; GSA Bull. 125 523-538.

De Sarkar S, Mathew G, Pande K, Phukon P and Singhvi A K 2014 Drainage migration and out of sequence thrusting in Bhalukpong, western Arunachal Himalaya, India; J. Geodyn. 81 1-16.

Godin L, Grujic D and Law R D et al. 2006 Channel flow, extrusion and extrusion in continental collision zones: An introduction; In: Channel flow, extrusion and extrusion in continental collision zones (eds) Law R D and Searle M P, Geol. Soc. London Spec. Publ. 268 1-23.

Goswami T K and Sarmah R K 2013 Conditions of compaction and development of diagenetic microstructures in the Dafla and Subansiri sandstones, western Arunachal Pradesh, India; European Sci. J. 9(12).

Kelty T K, Dubey C S and Yin A 2004 Structure and crustal shortening of the Subhimalayan fold and thrust belt, western Arunachal Pradesh, NE India; Him. J. Sci. 2175.

Khanal S and Robinson D M 2013 Upper crustal shortening and forward modeling of the Himalayan thrust belt along the Budhi-Gandaki River, central Nepal; Int. J. Earth Sci. 102 1871-1891.

Khanal S, Robinson D M, Kohn M J and Mandal S 2015a Evidence for a far-traveled thrust sheet in the Greater Himalayan thrust system, and an alternative model to building the Himalaya; Tectonics 34(1) 31-52.

Khanal S, Robinson D M, Mandal S and Simkhada P 2015b Structural, geochronological and geochemical evidence for two distinct thrust sheets in the 'Main Central thrust zone', the Main Central thrust and Ramgarh-Munsiari thrust: Implications for upper crustal shortening in central Nepal; In: Tectonics of the Himalaya (eds) Mukherjee S, Carosi R, van der Beek P, Mukherjee B K and Robinson D, Geol. Soc. London, Spec. Publ. 412 221-245.

Labaume P 1987 Syn-diagenetic deformation of a turbiditic succession related to submarine gravity nappe emplacement, Autapie Nappe, French Alps; Geol. Soc. London, Spec. Publ. 29 147-163.

Lang K and Huntington K W 2014 Antecedence of the Yarlung-Siang-Brahmaputra River, eastern Himalaya; Earth Planet. Earth Planet. Sci. Lett. 397 145-158.

Lang K A, Huntington K W, Burmester R and Housen B 2016 Rapid exhumation of the eastern Himalayan syntaxis since the late Miocene; GSA Bull. 128 1403-1422.

Mandal S, Robinson D M, Khanal S and Das O 2015 Redefining the tectonostratigraphic and structural architecture of the Almora klippe and the RamgarhMunsiari thrust sheet in NW India; In: Tectonics of the 
Himalaya (eds) Mukherjee S, Carosi R, van der Beek P, Mukherjee B K, Robinson D, Geol. Soc. London, Spec. Publ. 41 247-269.

Mandal S, Robinson D M, Kohn M J, Khanal S, Das O and Bose S 2016 Zircon U-Pb ages and Hf isotopes of the Askot klippe, Kumaun, northwest India: Implications for Paleoproterozoic tectonics, basin evolution and associated metallogeny of the northern Indian cratonic margin; Tectonics 35 965-982.

Martin A J 2017 A review of Himalayan stratigraphy, magmatism, and structure; Gond. Res. 49 42-80.

Mukherjee S 2012a A micro-duplex; Int. J. Earth Sci. 101 503.

Mukherjee S 2012b Tectonic implications and morphology of trapezoidal mica grains from the Sutlej section of the Higher Himalayan Shear Zone, Indian Himalaya; J. Geol. 120 575-590.

Mukherjee S 2013 Channel flow extrusion model to constrain dynamic viscosity and Prandtl number of the Higher Himalayan Shear Zone; Int. J. Eath Sci. 102 18111835 .

Mukherjee S 2015 A review on out-of-sequence deformation in the Himalaya; In: Tectonics of the Himalaya (eds) Mukherjee S, Carosi R, van der Beek P, Mukherjee B K and Robinson D, Geol. Soc. London, Spec. Publ. 412 67109.

Mukherjee S and Koyi H A 2010 Higher Himalayan Shear Zone, Sutlej section: Structural geology and extrusion mechanism by various combinations of simple shear, pure shear and channel flow in shifting modes; Int. J. Earth Sci. 99 1267-1303.

Mukherjee S, Carosi R, van der Beek P A, Mukherjee B K and Robinson D M 2015 Tectonics of the Himalaya: An introduction; Geol. Soc. London, Spec. Publ. 412 1-3.

Passchier C W K and Trouw R A J 2005 Microtectonics; 2nd edn, Springer.

Poblet J and Lisle R J 2011 Kinematic evolution and structural styles of fold-and-thrust belts; Geol. Soc. London, Spec. Publ. 349 1-24.

Schelling D, Cater J, Seago R and Ojha TP 1991 A balanced cross-section across the central Nepal Siwalik hills:
Hitauda to Amlekhganj; J. Fac. Sci. Hokkaido Univ. Ser. 23 1-9.

Srinivasan V 2003 Stratigraphy and Structure of Siwaliks in Arunachal Pradesh: A Reappraisal through Remote Sensing Techniques; J. Geol. Soc. Ind. 62 139-151.

Srivastava P and Mishra D K 2008 Morpho-sedimentary records of active tectonics at the Kameng river exit, NE Himalaya; Geomorphol. 96 187-198.

Tearpock D J and Bische R E 2002 Applied Subsurface Geological Mapping with Structural Methods; 2nd edn, Prentice Hall.

Thakur V C 1992 Geology of western Himalaya; 19 Pergamon Press.

Thakur V C 2013 Active tectonics of Himalayan Frontal Fault system; Int. J. Earth Sci. 102 1791-1810.

Thakur V C, Joshi M, Suresh N, Jayangondaperumal R and Singh A 2014 Partitioning of convergence in nortwest Sub-Himalaya: Estimation of late Quaternary uplift and convergence rates across the Kangara reentrant, North India; Int. J. Earth Sci. 103 1037-1056.

Verma P K and Tandon S K 1976 Geological observations in parts of Kameng district, Arunachal Pradesh (NEFA); Him. Geol. 6 259-286.

Valdiya K S 1998 The Dynamic Himalaya; Univ. Press (I) Ltd.

Valdiya K S 2003 Reactivation of Himalayan Frontal Fault: Implications; Curr. Sci. 85 1031-1040.

Yin A 2006 Cenozoic tectonic evolution of the Himalayan orogen as constrained by along-strike variation of structural geometry, extrusion history, and foreland sedimentation; Earth Sci. Rev. 76 1-131.

Yin A, Dubey C S, Kelty T K, Gehrels G E, Chou C Y, Grove M and Lovera O 2006 Structural evolution of the Arunachal Himalaya and implications for asymmetric development of the Himalayan orogen; Curr. Sci. 90 $1-12$.

Yin A, Dubey C S, Kelty T K, Harrison M, Chou C Y and Celerier J 2010 Geologic correlation of the Himalayan orogen and Indian craton: Part 2. Structural geology, geochronology, and tectonic evolution of the Eastern Himalaya; GSA Bull. 122 360-395. 